\title{
Obliquity forcing of low-latitude climate
}

\author{
J. H. C. Bosmans ${ }^{1,2, a, *}$, F. J. Hilgen ${ }^{1}$, E. Tuenter ${ }^{1,2, b}$, and L. J. Lourens ${ }^{1}$ \\ ${ }^{1}$ Faculty of Geosciences, Utrecht University, the Netherlands \\ ${ }^{2}$ Royal Netherlands Meteorological Institute (KNMI), the Netherlands \\ ${ }^{a}$ now at: Faculty of Geosciences, Utrecht University, the Netherlands \\ ${ }^{b}$ now at: Royal Netherlands Meteorological Institute (KNMI), the Netherlands \\ * Invited contribution by J. H. C. Bosmans, recipient of the EGU Outstanding Student Poster (OSP) Awards 2013.
}

Correspondence to: J. H. C. Bosmans (j.h.c.bosmans@uu.nl)

Received: 16 January 2015 - Published in Clim. Past Discuss.: 11 February 2015

Revised: 22 September 2015 - Accepted: 28 September 2015 - Published: 9 October 2015

\begin{abstract}
The influence of obliquity, the tilt of the Earth's rotational axis, on incoming solar radiation at low latitudes is small, yet many tropical and subtropical palaeoclimate records reveal a clear obliquity signal. Several mechanisms have been proposed to explain this signal, such as the remote influence of high-latitude glacials, the remote effect of insolation changes at mid- to high latitudes independent of glacial cyclicity, shifts in the latitudinal extent of the tropics, and changes in latitudinal insolation gradients. Using a sophisticated coupled ocean-atmosphere global climate model, ECEarth, without dynamical ice sheets, we performed two idealized experiments of obliquity extremes. Our results show that obliquity-induced changes in tropical climate can occur without high-latitude ice sheet fluctuations. Furthermore, the tropical circulation changes are consistent with obliquityinduced changes in the cross-equatorial insolation gradient, suggesting that this gradient may be used to explain obliquity signals in low-latitude palaeoclimate records instead of the classical $65^{\circ} \mathrm{N}$ summer insolation curve.
\end{abstract}

\section{Introduction}

The influence of obliquity (axial tilt) on low-latitude insolation is very small; the difference over tropical latitudes between high and low obliquity is less than $10 \mathrm{~W} \mathrm{~m}^{-2}$ in the summer or winter season (Fig. 1). Precession induces much larger changes in seasonal insolation, up to $100 \mathrm{~W} \mathrm{~m}^{-2}$ (Tuenter et al., 2003; Bosmans et al., 2015a). Therefore, a time series of (summer) insolation at the tropics $\left(23^{\circ} \mathrm{N}\right.$, roughly the Tropic of Cancer) reveals the periodicity of pre- cession ( $\sim 23 \mathrm{kyr})$, but the periodicity obliquity is almost absent ( $\sim 41 \mathrm{kyr}$; see black line at the top of Fig. 2 and power spectra in Fig. 3). Hence low-latitude insolation changes do not correlate well with low-latitude palaeoclimate records, which often reveal an obliquity signal next to precession (e.g. Lourens et al., 1996; Clemens et al., 1991). A better correlation to low-latitude palaeoclimate records is with $65^{\circ} \mathrm{N}$ summer insolation, which has a stronger obliquity signal than $23^{\circ} \mathrm{N}$ summer insolation (see red line in Figs. 2 and 3).

Many studies have therefore attributed the relatively strong obliquity signal in low-latitude palaeoclimate records to high-latitude mechanisms. For instance, dust flux records from both the (sub)tropical Atlantic and the Arabian Sea concur with obliquity-paced global climate cycles, suggesting a close link between changes in low-latitude aridity and glacial variability (Bloemendal and deMenocal, 1989; deMenocal et al., 1993; Tiedemann et al., 1994; deMenocal, 1995). Several other proxy studies, however, find lowlatitude obliquity signals at times when glacial cycles were much smaller or even absent (Lourens et al., 1996, 2001; Hilgen et al., 1995, 2000; Sierro et al., 2000). In particular, obliquity-controlled interference patterns in Mediterranean sapropels are present not only in the Pleistocene (Lourens et al., 1996) but also in the warmer Pliocene and Miocene (Hilgen et al., 1995, 2003; Zeeden et al., 2014). Sapropels are generally thought to be related to African monsoon strength through runoff from African rivers into the Mediterranean (Rossignol-Strick, 1983, 1985), which would indicate that monsoon intensity is affected by obliquity both before and after major Northern Hemisphere $(\mathrm{NH})$ glacial cycles determined global climate. Furthermore, in the late Pliocene 

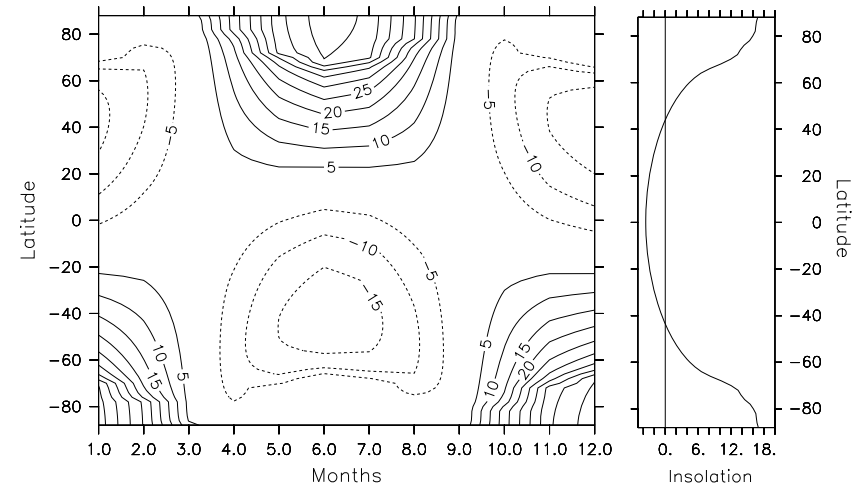

Figure 1. Insolation difference between $T_{\max }\left(24.45^{\circ}, T\right.$ for tilt) and $T_{\min }\left(22.05^{\circ}\right)$. On the left, insolation difference in $\mathrm{W} \mathrm{m}^{-2}$ is given per month on the $x$ axis and latitude on the $y$ axis. On the right, annual mean insolation difference is given, also in $\mathrm{W} \mathrm{m}^{-2}$.

and Pleistocene, phase relations suggest that the obliquity influence on sapropel formation and North African aridity did not proceed indirectly via ice driven responses but more directly via summer insolation (Lourens et al., 1996, 2010). In addition, colour changes associated with carbonate dilution cycles in north-western Africa and Spain reveal precession-obliquity interference patterns similar to those found in Mediterranean sapropels (Hilgen et al., 2000; Sierro et al., 2000). Also, others have ruled out global ice volume as a primary forcing mechanism for the occurrence of obliquityrelated variability in Indian monsoon strength as inferred from sediment records of the Arabian Sea (Clemens et al., 1991; Clemens and Prell, 2003).

Hence the North African and Indian monsoons may respond to obliquity independent of high-latitude ice growth and decay. The driving mechanism of obliquity-induced climate change over the tropics is yet poorly understood, since the influence of obliquity on low-latitude insolation is small. Some studies have suggested that the obliquity signal in the tropics is related to a local forcing mechanism. RossignolStrick (1983) introduced a monsoon index (M) based on the summer insolation difference between the Tropic of Cancer and the Equator, recognizing that the North African monsoon depends on the strength of the Saharan heat trough as well as on the pressure gradient between the heat trough and the Equator (M, green line in Figs. 2 and 3). The summer insolation difference between these two latitudes introduces an obliquity signal, though too small to explain the characteristic obliquity interference patterns in the Mediterranean sapropels over the past 14 million years (Lourens et al., 1996; Hilgen et al., 1995, 2003; Zeeden et al., 2014). Since then, cross-equatorial (inter-hemispheric) insolation gradients have been introduced (e.g. Reichart, 1996; Leuschner and Sirocko, 2003), which acknowledge the role of crossequatorial moisture transport (as part of the winter hemisphere Hadley cell) in monsoon strength both at present and on orbital timescales (e.g. Clemens et al., 1996; Mantsis et al., 2014; Bosmans et al., 2015a). Here we focus on the summer inter-tropical insolation gradient (SITIG), $I_{23^{\circ} \mathrm{N}^{-}}$ $I_{23^{\circ} \mathrm{S}}$ on 21 June (light-blue line in Figs. 2 and 3), which shows a better fit to the sapropel record than insolation at $23^{\circ} \mathrm{N}$ or monsoon index, $\mathrm{M}$ (see Sect. 3.1). A stronger interhemispheric insolation contrast drives a stronger (winter) Hadley circulation (Mantsis et al., 2014) and thus a stronger cross-equatorial moisture transport into the summer hemisphere. Inter-hemispheric insolation gradients can therefore explain the obliquity signal in the sapropels (through monsoonal runoff) as well as the Indian ocean proxy records without high-latitude mechanisms. The insolation curves and insolation gradients are discussed in more detail in Sect. 3.1. We note that obliquity may also affect climate through other insolation gradients (e.g. Reichart, 1996; Leuschner and Sirocko, 2003; Raymo and Nisancioglu, 2003; Antico et al., 2010; Mantsis, 2011), which will be considered in the Discussion section (Sect. 4).

Modelling results previously suggested that the influence of obliquity on the tropics resulted from high-latitude forcing, i.e. consistent with the application of the $65^{\circ} \mathrm{N}$ insolation curve. According to Tuenter et al. (2003), an increase in obliquity results in higher temperature and humidity at high latitudes. The resulting strengthening of southward moisture transport, as well as a stronger Asian low-pressure system, acts to strengthen the monsoons. This remote control (north of $30^{\circ} \mathrm{N}$ ) accounts for $80-90 \%$ of the total obliquity signal in the North African monsoon, without any changes in land ice (Tuenter et al., 2003). The model they used is EC-Bilt (Opsteegh et al., 1998), a quasi-geostrophic climate model of intermediate complexity. Due to simplifications in model physics as well as low resolution, one can question its suitability for modelling tropical climate. Bosmans et al. (2015a) showed, using a state-of-the-art, high-resolution, fully coupled ocean-atmosphere model, EC-Earth, that mechanisms behind the orbital forcing of the North African monsoon are very different than previously established from the EC-Bilt model. From EC-Earth it emerged that while the effect of precession was larger, a clear obliquity signal appeared in the monsoon as well without high-latitude influences.

In this study we use the EC-Earth model to investigate the influence of obliquity signal on the entire tropics, without land ice changes. Specifically, we investigate whether our results are in line with the SITIG mechanism. The model and experimental setup are described in Sect. 2. Section 3.1 describes insolation curves that are used in palaeoclimate literature and describes the SITIG mechanism in greater detail. Section 3.2 describes EC-Earth model results such as changes in atmospheric circulation that can help explain palaeoclimate records, which usually reflect changes in precipitation (for example dust records or the sapropels) and/or wind (such as Arabian Sea records). The results are followed by a discussion in Sect. 4 and a conclusion in Sect. 5. Figures 


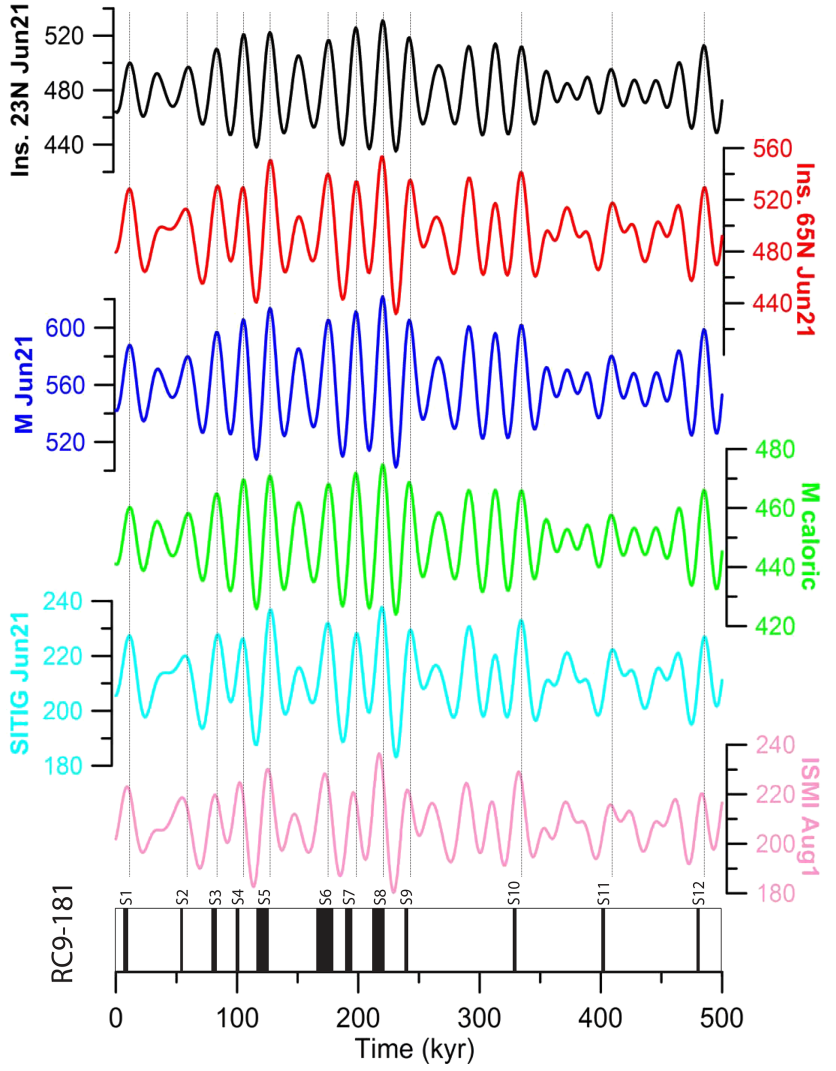

Figure 2. Insolation in $\mathrm{W} \mathrm{m}^{-2}$ over the past $500 \mathrm{kyr}$ at $23^{\circ} \mathrm{N}$ (black) and $65^{\circ} \mathrm{N}$ (red) and insolation indices $\mathrm{M}$ (blue, green; Rossignol-Strick, 1985), SITIG (light blue; Reichart, 1996) and ISMI (pink; Leuschner and Sirocko, 2003), based on the astronomical solution of Laskar et al. (2004), using AnalySeries (Paillard et al., 1996). All curves are based on 21 June insolation, except M caloric (green, summer half-year) and ISMI (pink, 1 August). The lowest part of the figure shows sapropels in core RC9-181 (Cita et al., 1977; Vergnaud-Grazzini et al., 1977). The vertical lines indicate 21 June insolation maxima/precession minima. We note that the obliquity signal also appears in older parts of the insolation and sapropel records (e.g. Lourens et al., 1996; Hilgen et al., 1995, 2003; Zeeden et al., 2014).

of model results show the difference between high and low obliquity.

\section{Model and experimental setup}

Here we use the new, state-of-the-art, high-resolution, fully coupled ocean-atmosphere model, EC-Earth, to investigate influence of obliquity on tropical climate. EC-Earth is used for the Fifth Assessment Report of the Intergovernmental Panel on Climate Change (Hazeleger et al., 2011; Flato et al., 2013; Collins et al., 2013) and was also used to perform the pre-industrial and mid-Holocene experiments of the Paleoclimate Modelling Intercomparison Project (Bosmans et al., 2012). We performed two idealized obliquity experiments, using the same experimental setup as Tuenter et al. (2003): one with a low obliquity $\left(22.04^{\circ}, T_{\min }\right)$ and one with a high obliquity $\left(24.45^{\circ}, T_{\max }\right) . T$ stands for tilt (obliquity). Eccentricity is set to zero, so the Earth's orbit is perfectly round and there is no influence of precession. All other boundary conditions are fixed at pre-industrial levels, and therefore there are no changes in land ice or in vegetation. The experiments were run for 100 years each, which is sufficient for atmospheric and surface variables, including sea surface temperature, to equilibrate to the insolation forcing. For more details see Bosmans et al. (2015a), where the same obliquity experiments are used to investigate the North African monsoon.

\section{Results}

\subsection{Insolation curves}

Obliquity-induced changes in insolation are shown in Fig. 1. When obliquity is high $\left(T_{\max }\right)$, insolation on the summer hemisphere is increased, especially near the poles. At the tropics, insolation changes are small. Therefore, time series of summer insolation at low latitudes (for example $23^{\circ} \mathrm{N}$, black line in Figs. 2, 3) hardly shows variability on the $\sim 41 \mathrm{kyr}$ timescale of obliquity, whereas $65^{\circ} \mathrm{N}$ summer insolation has a relatively strong obliquity signal (red line in Figs. 2, 3). The latter therefore matches better with the sapropel record (sapropels from core RC9-181, as used by, for example, Rossignol-Strick, 1983, 1985, are shown at the bottom of Fig. 2). The occurrence of sapropels matches insolation peaks (precession minima) at $23^{\circ} \mathrm{N}$, but $23^{\circ} \mathrm{N}$ summer insolation cannot explain the thick-thin alternations in the sapropel record. For instance, sapropels S4 and S7 are thinner than S3 and S6 respectively, despite corresponding to stronger insolation at $23^{\circ} \mathrm{N}$. This thick-thin alternation in the sapropel record is related to obliquity (e.g. Lourens et al., 1996). The $65^{\circ} \mathrm{N}$ summer insolation, with a stronger obliquity signal than $23^{\circ} \mathrm{N}$ insolation, shows a better match to the sapropels, with strength of insolation peaks corresponding to sapropel thickness. The thick-thin alternation (precessionobliquity interference) is found not only in the last $500 \mathrm{kyr}$ (Fig. 2) but also in both Plio-Pleistocene (e.g. Lourens et al., 1996, 2001) and Miocene records (e.g. Hüsing et al., 2007; Zeeden et al., 2014).

The monsoon index (M) of Rossignol-Strick (1983) is given by $2 \times I_{23^{\circ}} \mathrm{N}-I_{0^{\circ}} \mathrm{N}$ for the caloric summer half-year (green line in Fig. 2). By introducing the insolation difference between the northern tropics $\left(\sim 23^{\circ} \mathrm{N}\right)$ and the Equator, an obliquity signal is present in M (Fig. 3). Here we also show the monsoon index $\mathrm{M}$ for 21 June instead of the summer half-year (dark-blue line), in order to show that part of the obliquity signal in $\mathrm{M}$ originates from taking the half-year insolation (Fig. 3). Despite having a stronger obliquity signal than $23^{\circ} \mathrm{N}$ insolation, $\mathrm{M}$ does not explain the thick-thin alternation in the sapropels (Fig. 2). 


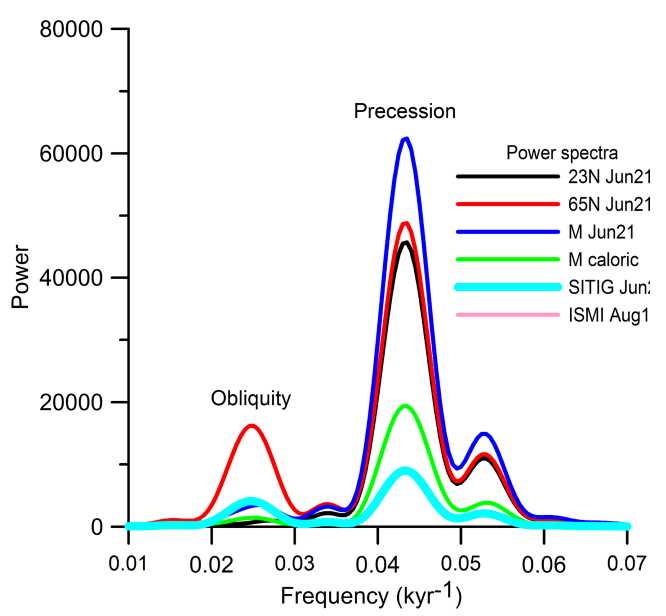

(a) Power spectrum

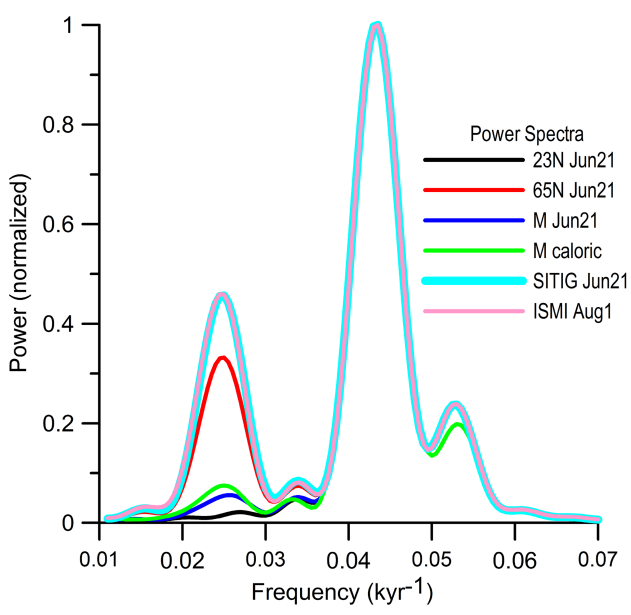

(b) Normalized power spectrum

Figure 3. Power spectra of insolation curves in Fig. 2. Panel (a) shows the power spectrum in an absolute sense and (b) the normalized power spectrum. For (b), each curve is divided by its peak power at $\sim 0.043 \mathrm{kyr}^{-1}$.

Taking the insolation difference between two hemispheres, such as the summer inter-tropical insolation gradient (SITIG), $I_{23^{\circ}} \mathrm{N}^{-} I_{23^{\circ}} \mathrm{S}$ on 21 June (light-blue line in Fig. 2), results in an insolation curve very similar to that of $65^{\circ} \mathrm{N}$ on 21 June. In SITIG, the obliquity signal originates from the fact that, in contrast to precession, obliquity induces insolation increases on one hemisphere and, at the same time, insolation decreases on the other hemisphere (Fig. 1). Therefore SITIG has a much stronger obliquity signal, relative to precession, than insolation at a single low latitude. At times of high obliquity $\left(T_{\max }\right)$ the insolation gradient over the tropics (SITIG) is stronger than during low obliquity; it varies between $\sim 238$ and $\sim 183 \mathrm{~W} \mathrm{~m}^{-2}$ over the past $500 \mathrm{kyr}$. This also holds for SITIG in aus- tral summer $\left(I_{23^{\circ}} \mathrm{S}-I_{23^{\circ} \mathrm{N}}\right.$ on 21 December). When SITIG is stronger, the inter-hemispheric pressure gradient between the two limbs of the winter hemisphere Hadley cell is strengthened, which drives monsoon winds into the summer hemisphere. A strong SITIG may therefore result in stronger cross-equatorial winds and moisture transport into the summer hemisphere, associated with an intensified winter Hadley cell (Reichart, 1996). A schematic overview of the effect of obliquity on the (winter) Hadley cell given in Fig. 11 of Mantsis et al. (2014).

Like insolation at $65^{\circ} \mathrm{N}$ on 21 June, SITIG matches the sapropel record, including the obliquity-induced thick-thin alternations (Fig. 2). An insolation gradient similar to SITIG was introduced by Leuschner and Sirocko (2003), the Indian summer monsoon index $\left(I_{30^{\circ} \mathrm{N}}-I_{30^{\circ} \mathrm{S}}\right.$ at 1 August $)$. Despite a small lag (due to ISMI being defined on 1 August and SITIG on 21 June) they are rather similar and both have a relatively strong obliquity signal (Fig. 3). The $65^{\circ} \mathrm{N}$ insolation is often used to interpret palaeoclimate records because of the matching patterns, but it requires an explanation of how highlatitude insolation affects low-latitude climate. Here, we investigate whether changes in tropical climate and circulation patterns match the SITIG mechanism based on the EC-Earth experiments (next Sect. 3.2).

Note that we focus on (peak) summer insolation and climate, under the assumption that the palaeoclimate proxies such as the sapropels are influenced by seasonal phenomena such as monsoons. Changes in obliquity result in annual mean insolation changes (right side of Fig. 1) per latitude as well as changes in the annual mean Equator-to-pole insolation gradient. This is briefly discussed in Sect. 4.3.

\subsection{EC-Earth obliquity experiments}

EC-Earth shows statistically significant differences in net precipitation over the tropics between high $\left(T_{\max }\right)$ and low obliquity $\left(T_{\min }\right.$, Fig. 4). Precipitation differences between $T_{\max }$ and $T_{\min }$ reach up to and over $100 \%$, for instance over the Sahara and South America (not shown). There is an overall intensification of the North African and Asian monsoons during boreal summer (June-July-August), with a redistribution of precipitation from ocean to land and stronger landward monsoon winds (Fig. 4; Bosmans et al., 2015a). Differences in wind speed can also be as large as $100 \%$, for instance in the areas of summer monsoon winds into North Africa and India (see Fig. 5). Over the equatorial and southern Pacific, wind speed changes in boreal summer are small, while winds around the North Pacific as well as the North Atlantic highs are generally stronger. During austral summer (December-January-February) net precipitation and wind changes are smaller than during boreal summer, likely related to the smaller land mass and therefore weaker monsoons on the Southern Hemisphere (SH). The largest net precipitation increases occur over part of the southern African summer monsoon regions as well as the Atlantic and Indian 
Ocean, while net precipitation over the NH tropics is reduced (Fig. 4b).

Our experiments indicate strengthened surface winds towards the summer hemisphere during $T_{\max }$ (Fig. 4a and b), in agreement with a stronger SITIG during $T_{\max }$ (see Sect. 3.1). The zonal mean cross-equatorial surface winds are northward, and they are indeed stronger during boreal summer, extending slightly further into the NH (Fig. 6a). With these stronger surface winds the moisture transport into the $\mathrm{NH}$ is strengthened as well during $T_{\max }$ (Fig. 6b). Moisture transport into the North African and Asian monsoon areas is generally higher during boreal summer, with enhanced northward cross-equatorial transport mostly over the Indian Ocean (see Fig. 7a). Changes over the Pacific are small, which could be related to the absence of land masses which have a stronger response to insolation changes.

During austral summer the zonal mean southward crossequatorial surface winds are stronger when obliquity is high ( $\left.T_{\max }\right)$, extending slightly further into the $\mathrm{SH}$ (Fig. 6c). Therefore more moisture is transported southward across the tropics (Fig. 6d). Most of this increased southward moisture transport occurs over the Indian Ocean (Fig. 7b), where both wind and specific humidity are increased. Over the tropical Atlantic, specific humidity is lower during $T_{\max }$, so moisture transport is not increased despite the increase in wind speed (Fig. 4b).

The changes in surface winds and moisture transport can be related to changes in the (winter) Hadley cell. During boreal summer, the descending branch, centred at $\sim 20^{\circ} \mathrm{S}$, is strengthened, mostly at the northern side, with a slight weakening at the southern side during $T_{\max }$ (Fig. 8a). The same holds for the ascending branch, centred at $\sim 10^{\circ} \mathrm{N}$, so the winter Hadley cell is slightly stronger and extends further into the NH during boreal summer. During austral summer, the winter Hadley cell extends from a descending branch at $\sim 20^{\circ} \mathrm{N}$ to an ascending branch at $\sim 10^{\circ} \mathrm{S}$ (Fig. 8b). The additional rising branch at $5-10^{\circ} \mathrm{N}$ is most likely overestimated in the model due to a double Intertropical Convergence Zone over the Pacific, a feature that many models encounter (Lin, 2007). However, a strengthening of the winter Hadley cell can still be seen: both the descending and ascending branches are slightly stronger and extend further south during $T_{\max }$, in line with stronger southward surface winds.

While winds and moisture transport in the tropics are generally stronger during boreal and austral summer, they are weaker in the annual mean for $T_{\max }$ (Figs. 4c, 6e, 6f, 7c). This weakening can be related to the obliquity-induced redistribution of annual mean insolation from low to high latitudes during $T_{\max }$, resulting in weakening of the Equator-topole insolation gradient. Therefore annual mean meridional winds and moisture transport as well as the annual mean Hadley circulation are weaker (Fig. 8c). Annual mean precipitation changes resemble mostly the JJA changes over the continents, and they reflect both JJA and DJF changes over the oceans (Fig. 4c).

\section{Discussion}

We have shown, using the sophisticated model EC-Earth without land ice changes, that changes in low-latitude climate can arise as a direct result of obliquity-induced insolation changes. Here we discuss that these changes support the SITIG theory (Reichart, 1996; Leuschner and Sirocko, 2003), what the implications are for the interpretation of obliquity signals in low-latitude palaeoclimate records, and how obliquity-induced gradients may influence global climate.

\subsection{Model support for the SITIG theory}

The simulated changes in winter Hadley cell strength during boreal and austral summer are in accordance with the SITIG theory (Reichart, 1996; Leuschner and Sirocko, 2003). The SITIG theory (Sect. 3.1) states that an increased SITIG during high obliquity $\left(T_{\max }\right)$ is associated with an intensified winter Hadley cell and stronger cross-equatorial winds and moisture into the summer hemisphere. The winter Hadley cell is not entirely symmetric around the Equator (as is assumed in the original SITIG hypothesis; Reichart, 1996), nor are the changes in wind and moisture transport zonally invariant, likely due to differences in the land-sea distribution. Nonetheless, a stronger SITIG during high obliquity $\left(T_{\max }\right)$ results in stronger zonal mean winds and moisture transport into the summer hemisphere and a stronger Hadley cell in our EC-Earth results. The Hadley cell and the meridional winds and moisture transport also extend farther into the summer hemisphere. This is in agreement with the poleward shift of the latitude of the tropics during $T_{\max }$ (Rossignol-Strick, 1985; Larrasoaña et al., 2003). In these studies, meridional shifts in the Hadley cell and the tropics are associated with changes in the Equator-to-pole insolation gradient, which in summer has a strong obliquity component. These studies also suggest that the insolation gradient over the austral winter hemisphere causes temperature and trade wind changes that can influence the intensity and poleward penetration of the boreal summer monsoons. However, the winter (intrahemispheric) insolation gradient does not vary with obliquity but instead with precession (Davis and Brewer, 2009), so changes in winter (intra-hemispheric) hemisphere insolation gradients cannot be used to explain (low-latitude) obliquity signals. Also, we suggest that while the Hadley cell, and thus precipitation patterns, might indeed shift on obliquity timescales due to changes in the (summer) Equator-to-pole gradient, such a shift does not explain the changes in precipitation amounts, the strength of the Hadley circulation, and the strength of cross-equatorial winds and moisture transport that we identify in our obliquity experiments. Further sensitivity studies could shed more light on the relative roles of inter- and intra-hemispheric gradients (see Sect. 4.3). 


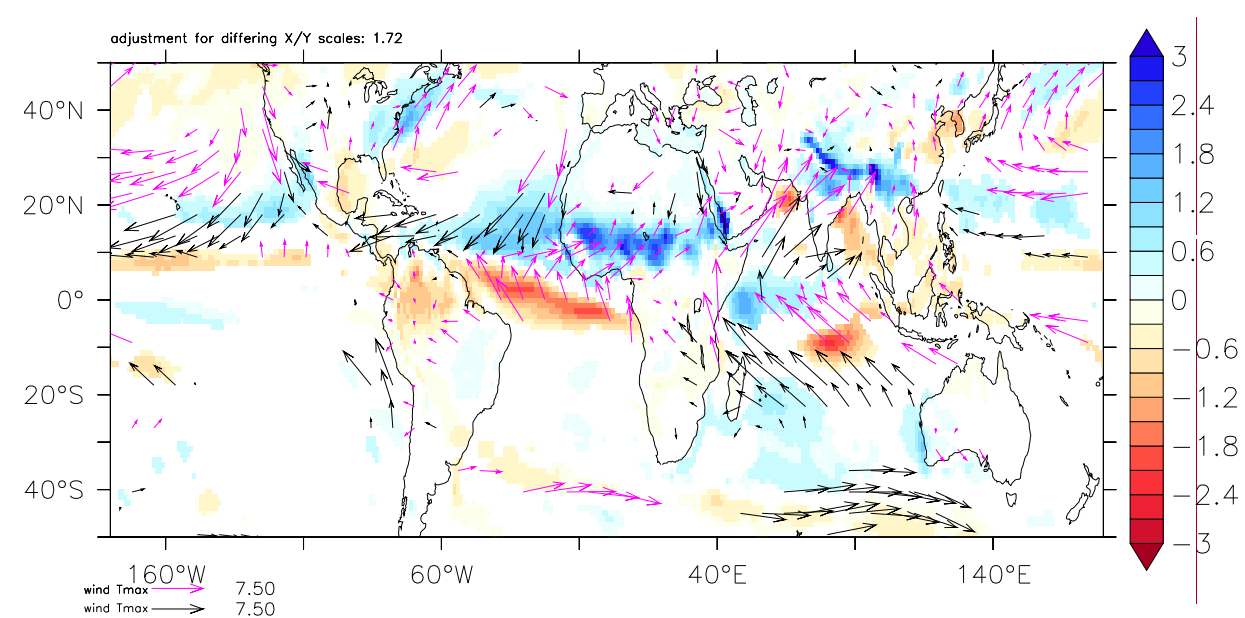

(a) June-July-August

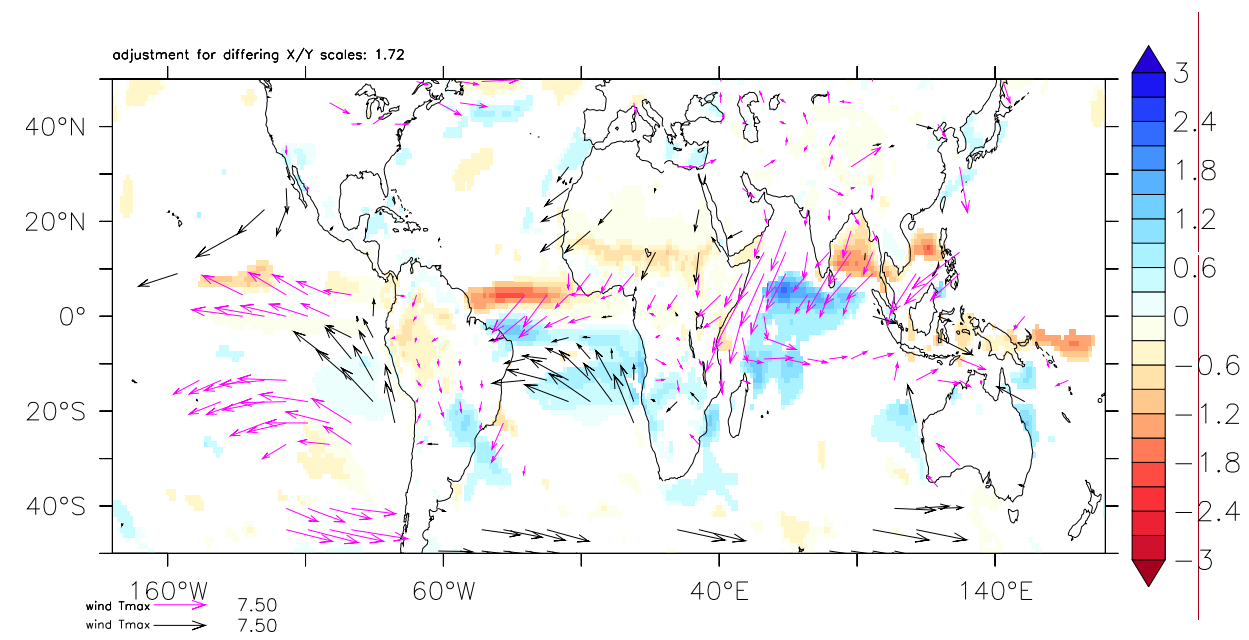

(b) December-January-February

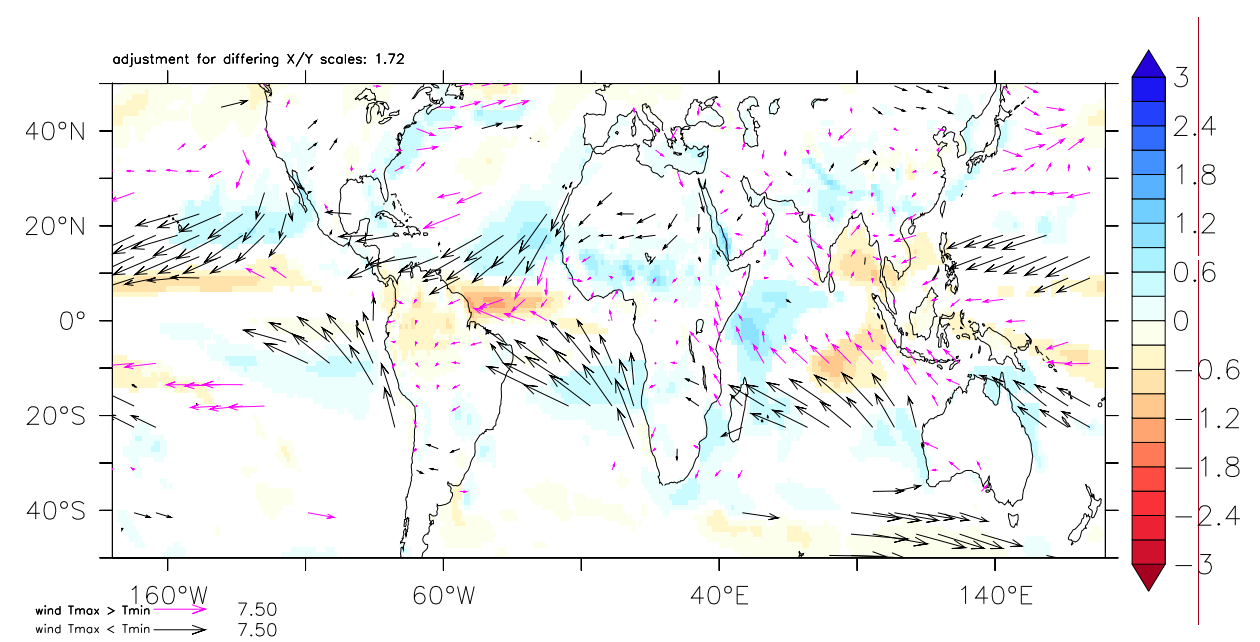

(c) Annual mean

Figure 4. Net precipitation differences and $T_{\max }$ surface wind for JJA (a), DJF (b) and annual mean (c). For net precipitation (precipitation minus evaporation), the differences $\left(T_{\max }\right.$ minus $T_{\min }$ ) are shown in $\mathrm{mm} \mathrm{day}^{-1}$. Overlain are the wind vectors for $T_{\max }$ in $\mathrm{m} \mathrm{s}^{-1}$. Purple vectors indicate larger wind speeds during $T_{\max }$ than during $T_{\min }$. Cross-equatorial winds are stronger in JJA (a) and DJF (b), mostly over the Atlantic and Indian Ocean. Every seventh arrow in the $x$ direction is drawn and every fourth arrow in the $y$ direction. Results are only shown where the differences in net precipitation or wind speeds are statistically significant at $95 \%$ (based on a two-sided Student $t$ test). The full wind field is given in Fig. 5. 


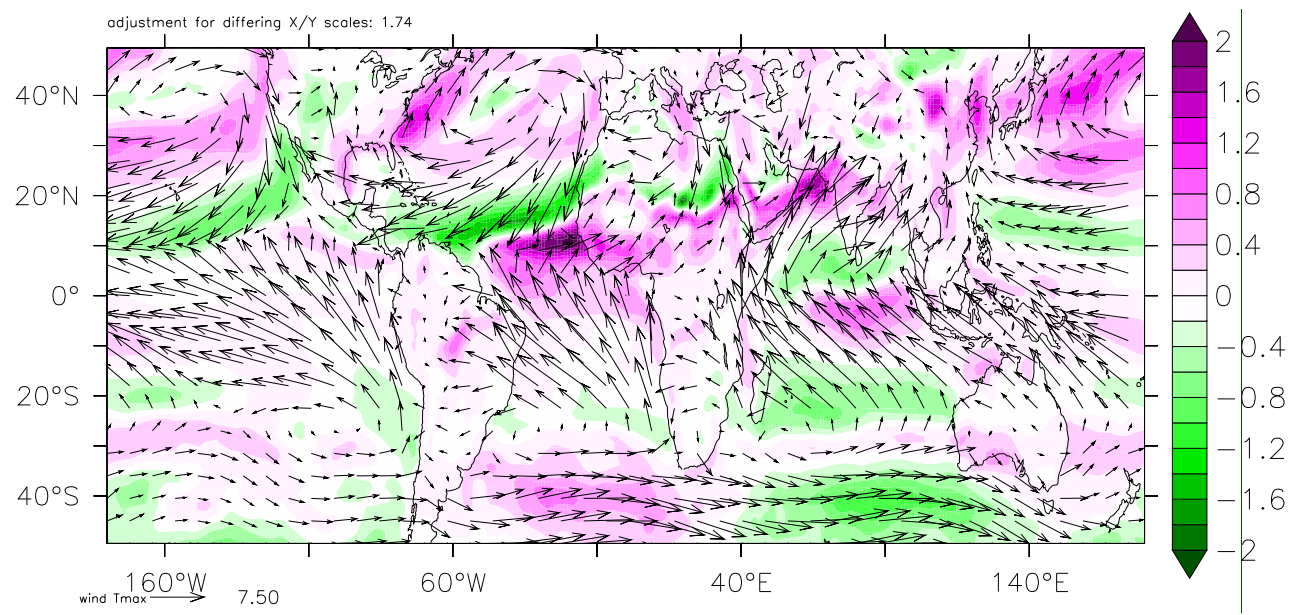

(a) June-July-August

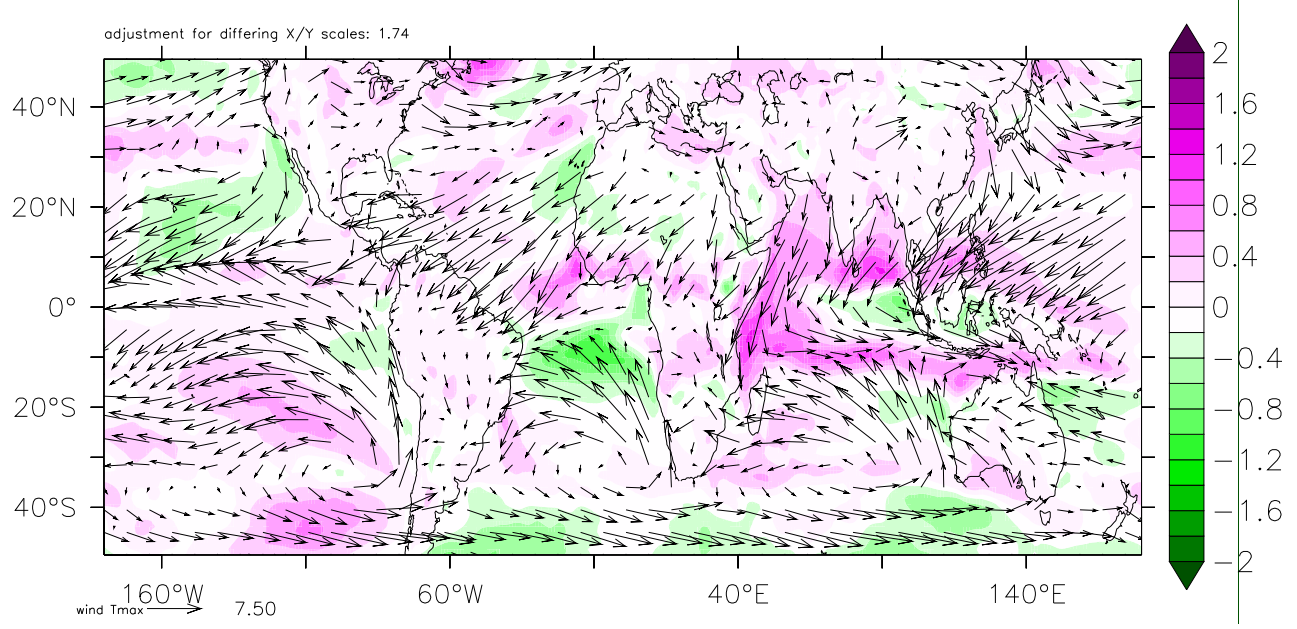

(b) December-January-February

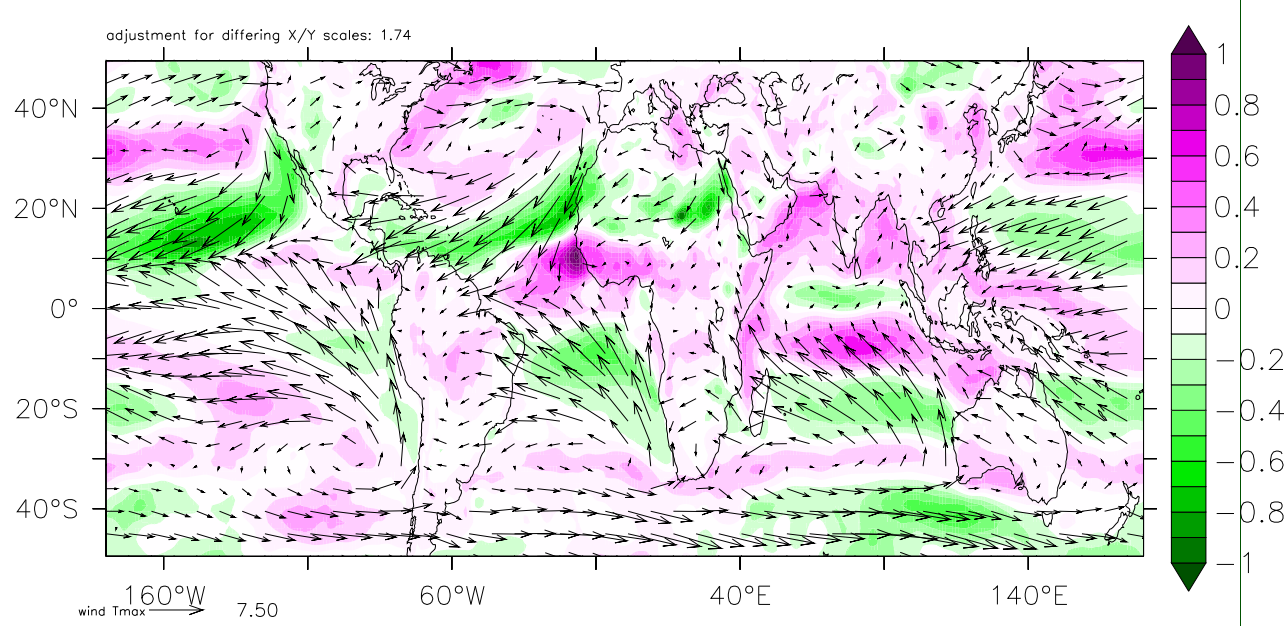

(c) Annual mean

Figure 5. Wind during $T_{\max }$ for JJA (a), DJF (b) and the annual mean (c), in $\mathrm{m} \mathrm{s}^{-1}$. The colour scale indicates the difference in wind speed between $T_{\max }$ and $T_{\min }$, in $\mathrm{m} \mathrm{s}^{-1}$. Note the different colour scale for the annual mean. Every ninth vector is shown in the $x$ direction, and every fifth in the $y$ direction. 

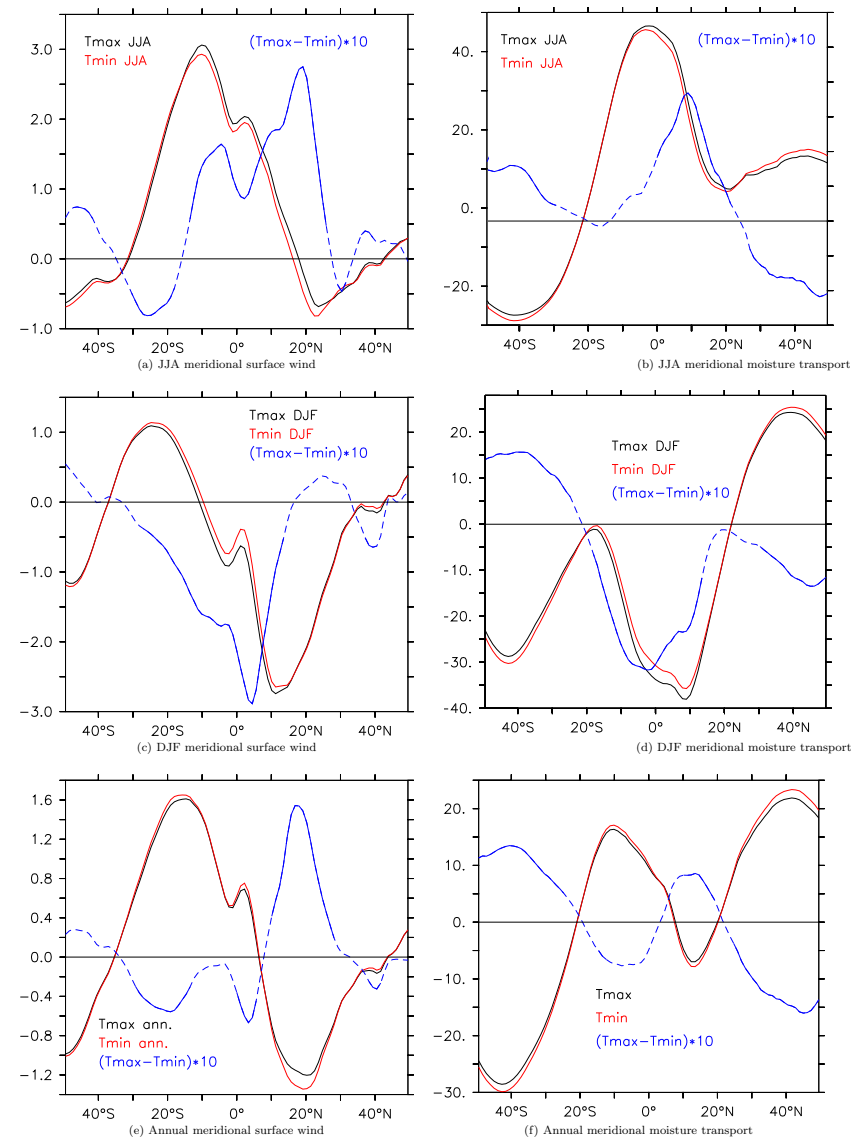

Figure 6. Zonal mean meridional surface wind and moisture transport for JJA (a, b), DJF (c, d) and annual mean (e, f). The wind is given in $\mathrm{m} \mathrm{s}^{-1}$, moisture transport in $\mathrm{kg}(\mathrm{ms})^{-1}$ for both $T_{\max }$ (black) and $T_{\min }$ (red) as well as the difference (blue, multiplied by 10 for clarity). Moisture transport is calculated as the massweighted vertical integral of specific humidity multiplied by horizontal wind. Positive values indicate northward wind or moisture transport, whereas negative values indicate southward. Wind and moisture transport into the summer hemisphere is stronger during $T_{\max }$ for JJA $(\mathbf{a}, \mathbf{b})$ and DJF $(\mathbf{c}, \mathbf{d})$. Solid parts of the blue line indicate where the difference is statistically significant at $95 \%$ (based on a two-sided Student $t$ test). Note that the vertical scales are different.

\subsection{Implications for the interpretation of palaeoclimate records}

Obliquity signals in low-latitude palaeoclimate records are often interpreted using the $65^{\circ} \mathrm{N} 21$ June insolation curve based on the matching precession-obliquity interference in the records and the $65^{\circ} \mathrm{N}$ insolation curve (Fig. 2). The model study of Tuenter et al. (2003), indicating that $\sim 80$ $90 \%$ of the obliquity signal in the North African monsoon is due to high-latitude influences, supported the use of the $65^{\circ} \mathrm{N}$ insolation curve. Some studies, on the other hand, have used a $P-\frac{1}{2} T$ curve to interpret palaeoclimate records (e.g. Lourens et al., 1996). This combination of the precession
$(P)$ and obliquity ( $T$ for tilt) parameters is very similar to the $65^{\circ} \mathrm{N} 21$ June insolation curve, but since $P-\frac{1}{2} T$ refers only to the orbital parameters and not to insolation, no direct assumptions on climate mechanisms are made. Our results, based on a much more sophisticated (and realistic) model with fixed land ice, clearly suggest a low-latitude mechanism for obliquity patterns at low latitudes through a direct response to changes in the cross-equatorial insolation gradient. Furthermore, there is a strong resemblance between SITIG $\left(I_{23^{\circ}} \mathrm{N}^{-} I_{23^{\circ} \mathrm{S}}\right.$ on 21 June) and the $65^{\circ} \mathrm{N} 21$ June insolation curve (Fig. 2; Reichart, 1996; Leuschner and Sirocko, 2003) as well as the $P-\frac{1}{2} T$ curve (Lourens et al., 2001). Hence, the widely applied $65^{\circ} \mathrm{N} 21$ June insolation curve (Tiedemann et al., 1994; Hilgen et al., 1995; Lourens et al., 1996, 2001; Hilgen et al., 2000; Sierro et al., 2000) needs to be reconsidered in favour of SITIG. SITIG instead of $65^{\circ} \mathrm{N} 21$ June insolation relies on a physical basis as described by the analysis presented here rather than pattern matching, and explains the obliquity influence on tropical climate independent of glacial-interglacial variability. It thus provides an explanation for the obliquity influence in the sapropel record of the past 14 million years during both the recent glacial cycles and the earlier warmer times. The suggestion that tuning to the $65^{\circ} \mathrm{N} 21$ June insolation curve might not be justified was also reached by Laepple and Lohmann (2009), but we note that their work is based on the present-day relationship between temperature and insolation to the past. This does not provide a climatic mechanism for obliquity signals at low latitudes, as low-latitude insolation has little obliquity variance and therefore results in a weak obliquity signal.

We note that the original SITIG theory was based on the Mediterranean sapropels (Reichart, 1996), which were originally linked to North African monsoon strength (e.g. Rossignol-Strick, 1985; Ruddiman, 2008) but have recently also been attributed to changes in Mediterranean winter precipitation through changes in Atlantic storm track activity (e.g. Tzedakis, 2007; Brayshaw et al., 2011; Kutzbach et al., 2013). In our obliquity experiments, changes in Mediterranean winter precipitation are unrelated to the Atlantic storm tracks but are of equal magnitude to summer monsoonal runoff into the Mediterranean. In terms of percentages, however, changes in monsoonal runoff are larger (Bosmans et al., 2015b). Another study stating the importance of cross-equatorial insolation gradients, Leuschner and Sirocko (2003), is based the insolation difference between $30^{\circ} \mathrm{N}$ and $30^{\circ} \mathrm{S}$, which drives Indian summer monsoon strength through pressure differences (pink line in Fig. 2). Leuschner and Sirocko (2003) state that their record of continental dust transport (indicative of monsoon strength) responds immediately to changes in the cross-equatorial insolation gradient. This matches with our results, showing changes in Indian summer monsoon strength as well as crossequatorial winds and moisture transport that are particularly strong over the Indian Ocean. Also, other palaeoclimate records in the Arabian Sea have been used to rule out global 


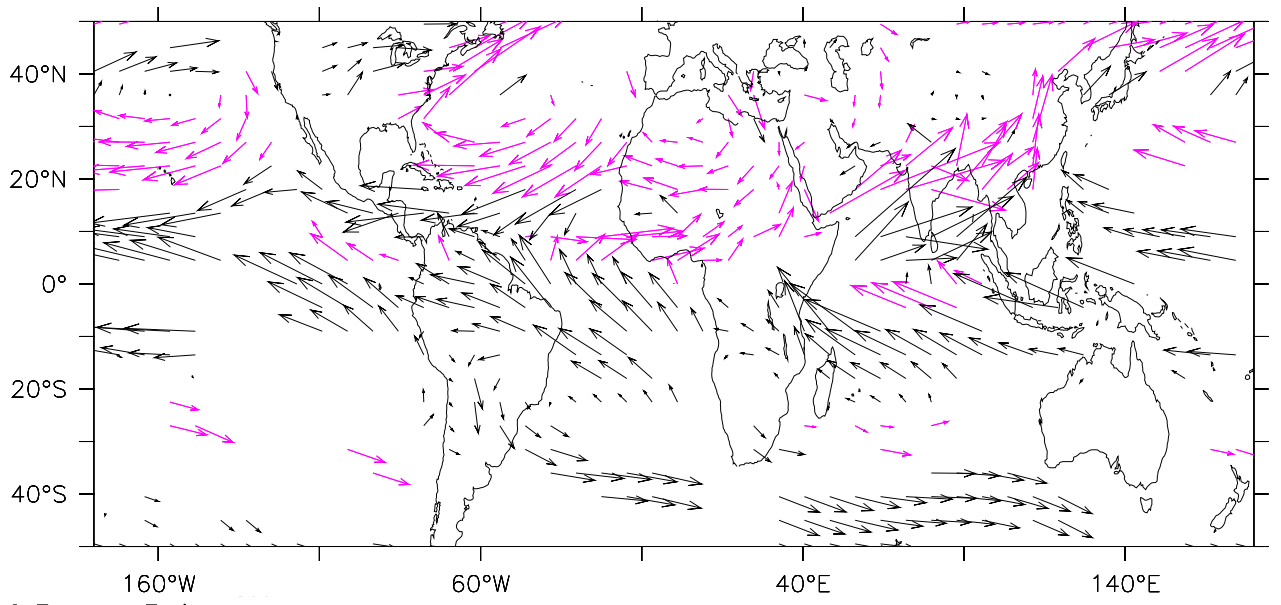

Q Tmax $>$ Tmin $\longrightarrow 200$

Q T max $<$ Tmin $>200$

(a) June-July-August

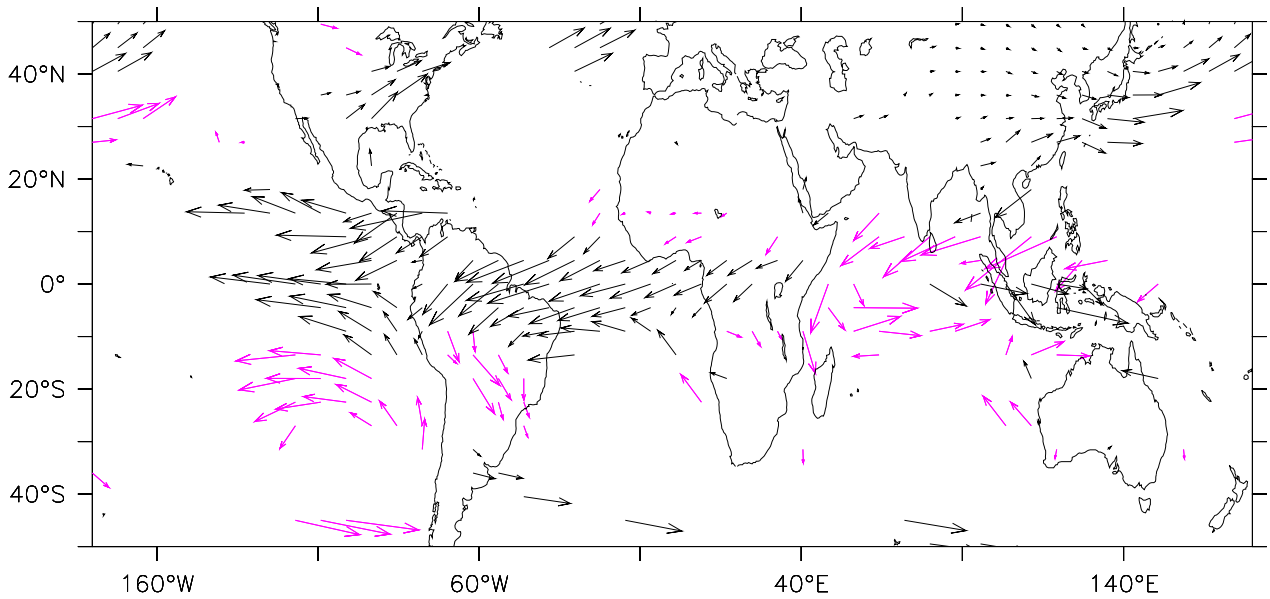

Q Tmax $>$ Tmin $\longrightarrow 200$

Q Tmax $<$ Tmin $\longrightarrow 200$

(b) December-January-February

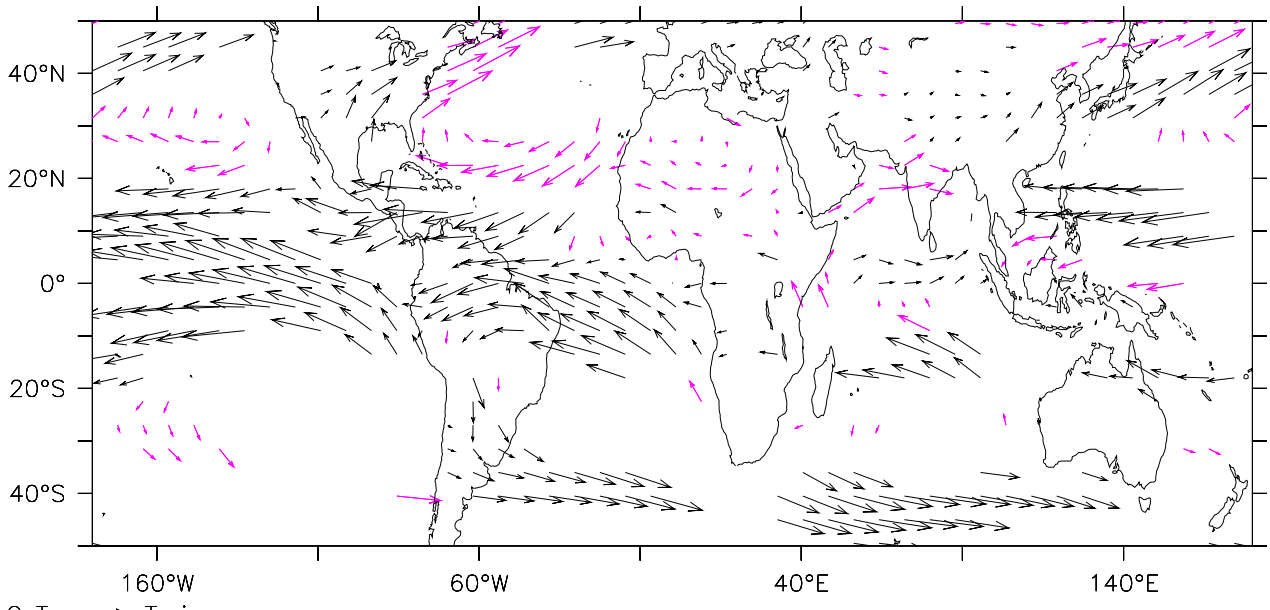

Q Tmax $>$ Tmin $\longrightarrow 200$

Q T max $<$ Tmin $>200$

(c) Annual mean

Figure 7. Moisture transport in $T_{\max }$ for JJA (a), DJF (b) and annual mean (c), vertically integrated, in $\mathrm{kg}(\mathrm{ms})^{-1}$. Purple vectors indicate larger moisture transport during $T_{\max }$ than during $T_{\min }$. Every seventh arrow in the $x$ direction is drawn and every fourth arrow in the $y$ direction. Results are only shown where the differences are statistically significant at $95 \%$ (based on a two-sided Student $t$ test). 

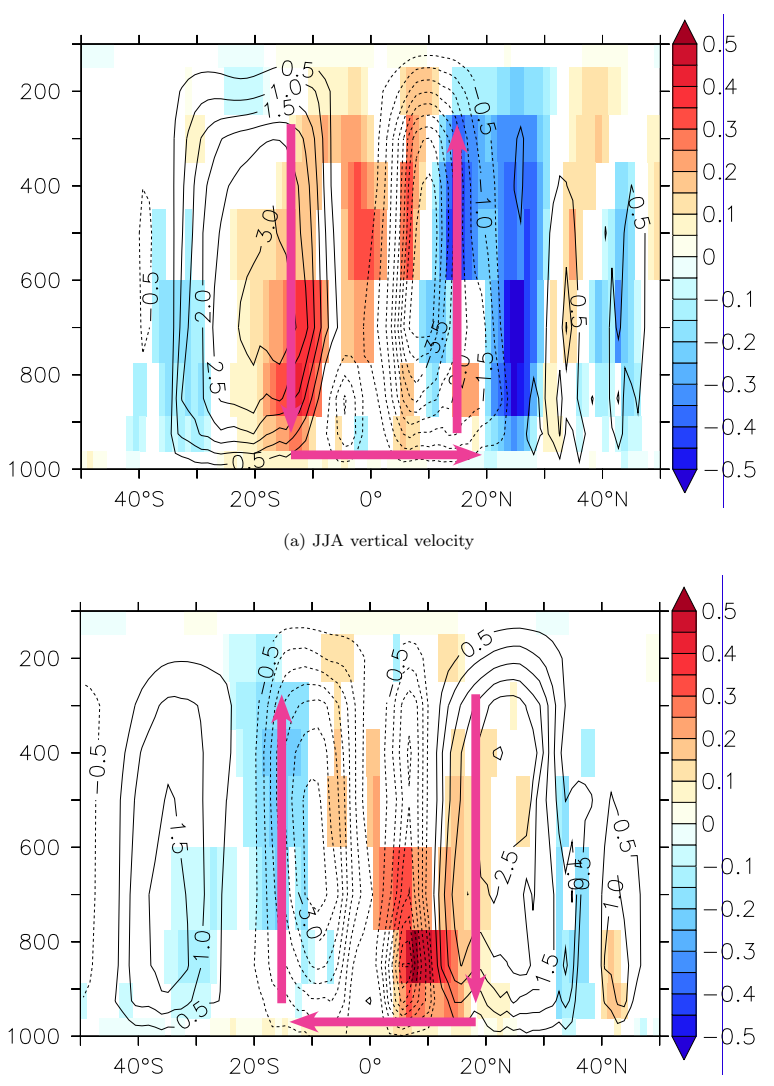

(b) DJF vertical velocity

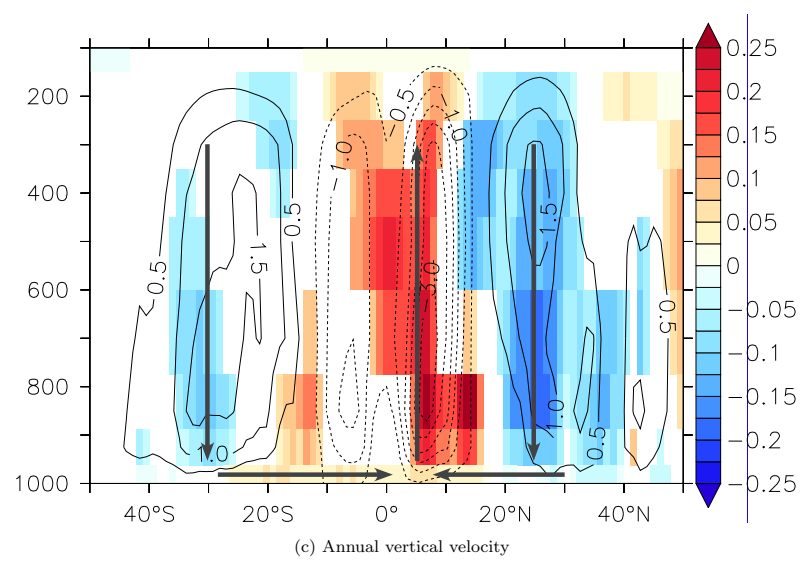

Figure 8. Zonal mean vertical velocity (omega, $10^{-2} \mathrm{~Pa} \mathrm{~s}^{-1}$ ) during $T_{\max }$ (contours) for JJA (a), DJF (b) and annual mean (c). Negative contours indicate upward motion (rising air), while positive contours indicate downward motion (sinking). The vertical scale ( $y$ axis) denotes height in hPa. The colours indicate the differences between $T_{\max }$ and $T_{\min }$, only shown where they are statistically significant at $95 \%$ (based on a two-sided Student $t$ test). The arrows indicate the direction of the air flow and are purple where the flow is stronger during $T_{\max }$ compared to $T_{\min }$, which is the case for boreal and austral summer (a, b). Black arrows indicate where the flow is weaker during $T_{\max }$. Hence the Hadley cell is stronger during $T_{\max }$ in both boreal and austral summer, and weaker in the annual mean. Note the different colour scale for the annual mean. ice volume as a primary forcing mechanism for the occurrence of obliquity-related variability in the Indian monsoon (Clemens and Prell, 2003; Clemens et al., 1991). Therefore we conclude that, despite the need to determine the relative role of (winter) precipitation over the Mediterranean in the formation of the sapropels, there is sufficient evidence from tropical and subtropical palaeoclimate records suggesting a low-latitude, direct response to obliquity forcing.

\subsection{Obliquity-induced gradients and their influence on global climate}

Leuschner and Sirocko (2003) and Reichart (1996) suggested that through monsoon-induced changes in atmospheric moisture content, a strong greenhouse gas, the summer inter-tropical insolation gradient (SITIG) may drive glacial-interglacial variability. Indeed we find a significant obliquity-induced change in cross-equatorial moisture transport (Fig. 6b, d). However, whether changes in atmospheric moisture content resulting from changes in low-latitude atmospheric circulation on orbital timescales can indeed result in global climate change will need to be investigated with longer model experiments including dynamic ice sheets (not included in EC-Earth). Furthermore, the role of precessioninduced changes in moisture content would need to be assessed as well.

Another mechanism by which obliquity can affect highlatitude climate and glacial cycles through latitudinal insolation gradients has been proposed by Raymo and Nisancioglu (2003), Vettoretti and Peltier (2004), Antico et al. (2010) and Mantsis (2011). These studies suggest that the poleward transport of heat, moisture and latent energy is increased during minimum obliquity due to the intensified intra-hemispheric (Equator-to-pole) insolation and temperature gradient. The increased moisture transport towards the poles combined with low polar temperatures during low obliquity is favourable for ice growth. In our EC-Earth experiments we also find stronger poleward moisture transport outside the tropics during minimum obliquity $\left(T_{\min }\right)$ during both boreal and austral summer as well as in the annual mean (Fig. 6b, d). The response to changes in the Equator-to-pole insolation and temperature gradient can be further intensified by albedo changes. In our experiments, land ice is fixed but sea ice at the poles responds to polar insolation changes (not shown). Furthermore, changes in poleward energy transport by ocean currents can play a role in obliquity's effect on global climate (Khodri et al., 2001; Jochum et al., 2012; Mantsis et al., 2014). In order to determine the relative role of tropical circulation changes through inter-hemispheric insolation gradients (SITIG), compared to changes in poleward energy and moisture transport in both atmosphere and ocean through intra-hemispheric gradients, further sensitivity experiments are necessary. Such experiments should include dynamic ice sheets and should be run longer for ice sheets and the (deep) ocean to equilibrate to the obliquity forcing. 
Also, experiments with insolation changes only over the tropics can be considered in order to test the effect of inter- versus intra-hemispheric insolation gradients. At this point such experiments are not yet feasible with the EC-Earth model. Experiments testing the sensitivity to obliquity changes under different precession and/or green house gas conditions should be considered as well (e.g. Rachmayani et al., 2015).

\section{Conclusions}

The low-latitude SITIG mechanism proposed here is fundamentally different from high-latitude mechanisms previously proposed to explain the obliquity patterns at low latitudes. Our results, based on the sophisticated model EC-Earth, suggest that these patterns may arise from a direct response to changes in the cross-equatorial insolation gradient, i.e. without any influence of ice sheets or other high-latitude mechanisms. Despite such mechanisms, related to ice sheets and/or Equator-to-pole gradients, requiring further research, our results suggest that the widely applied $65^{\circ} \mathrm{N} 21$ June insolation curve needs to be reconsidered in favour of SITIG.

Acknowledgements. The EC-Earth experiments were performed at KNMI using ECMWF facilities. This work was part of J. Bosmans' PhD project, funded by a "Focus en Massa" grant at Utrecht University. We thank the editor and two anonymous reviewers for their constructive remarks, which helped to improve this paper. M. L. Goudeau is acknowledged for her help with Fig. 2.

Edited by: A. Paul

\section{References}

Antico, A., Marchal, O., Mysak, L., and Vimeux, F.: Milankovitch Forcing and Meridional Moisture Flux in the Atmosphere: Insight from a Zonally Averaged Ocean-Atmosphere Model, J. Climate, 23, 4841-4855, 2010.

Bloemendal, J. and deMenocal, P.: Evidence for a change in the periodicity of tropical climate cycles at 2.4 Myr from wholecore magnetic susceptibility measurements, Nature, 342, 897900, 1989.

Bosmans, J. H. C., Drijfhout, S. S., Tuenter, E., Lourens, L. J., Hilgen, F. J., and Weber, S. L.: Monsoonal response to midholocene orbital forcing in a high resolution GCM, Clim. Past, 8, 723-740, doi:10.5194/cp-8-723-2012, 2012.

Bosmans, J. H. C., Drijfhout, S. S., Tuenter, E., Hilgen, F. J., and Lourens, L. J.: Response of the North African summer monsoon to precession and obliquity forcings in the EC-Earth GCM, Clim. Dynam., 44, 279-297, doi:10.1007/s00382-014-2260-z, 2015a.

Bosmans, J. H. C., Drijfhout, S. S., Tuenter, E., Hilgen, F. J., Lourens, L. J., and Rohling, E. J.: Precession and obliquity forcing of the freshwater budget over the Mediterranean, Quaternary Sci. Rev., 123, 16-30, doi:10.1016/j.quascirev.2015.06.008, $2015 b$.

Brayshaw, D. J., Rambeau, C. M. C., and Smith, S. J.: Changes in Mediterranean climate during the Holocene: Insight from global and regional climate modelling, Holocene, 21, 15-31, doi:10.1177/0959683610377528, 2011.

Cita, M. B., Vergnaud-Grazzini, C., Robert, C., Chamley, H., Ciaranfi, N., and d'Onofrio, S.: Paleoclimatic record of a long deep sea core from the eastern Mediterranean, Quaternary Res., 8, 205-235, 1977.

Clemens, S., Prell, W., Murray, D., Shimmield, G., and Weedon, G.: Forcing mechanisms of the Indian Ocean monsoon, Nature, 353, 720-725, 1991.

Clemens, S. C. and Prell, W. L.: A 350,000 year summer-monsoon multi-proxy stack from the Owen Ridge, Northern Arabian Sea, Mar. Geol., 201, 35-51, 2003.

Clemens, S. C., Murray, D. W., and Prell, W. L.: Nonstationary phase of the Plio-Pleistocene Asian monsoon, Science, 274, 943 948, 1996.

Collins, M., Knutti, R., Arblaster, J., Dufresne, J., Fichefet, T., Friedlingstein, P., Gao, X., Gutowski, W., Johns, T., Krinner, G., Shongwe, M., Tebaldi, C., Weaver, A., and Wehner, M.: Longterm climate change: projections, commitments and irreversibility, Working Group 1 Contribution to the IPCC Fifth Assessment Report-Climate Change: The Physical Science Basis, 10291136, 2013.

Davis, B. A. S. and Brewer, S.: Orbital forcing and the role of the latitudinal insolation/temperature gradient, Clim. Dynam., 32, 143-165, doi:10.1007/s00382-008-0480-9, 2009.

deMenocal, P. B.: Plio-Pleistocene African climate, Science, 270, 53-59, 1995.

deMenocal, P. B., Ruddiman, W. F., and Pokras, E. M.: Influences of high- and low-latitude processes on African terrestrial climate: Pleistocene eolian records from equatorial Atlantic ocean drilling program site 663, Paleoceanography, 8, 209-242, 1993.

Flato, G., Marotzke, J., Abiodun, B., Braconnot, P., Chou, S., Collins, W., Cox, P., Driouech, F., Emori, S., Eyring, V., Forest, C., Gleckler, P., Guilyardi, E., Jakob, C., Katssov, V., Reason, C., and Rummukainen, M.: Chapter 9: Evaluation of climate models, Working Group 1 Contribution to the IPCC Fifth Assessment Report-Climate Change: The Physical Science Basis, 74-866, 2013.

Hazeleger, W., Wang, X., Severijns, C., Stefanescu, S., Bintanja, R., Sterl, A., Wyser, K., Semmler, T., Yang, S., van den Hurk, B., van Noije, T., van der Linden, E., and van der Wiel, K.: EC-Earth V2.2: description and validation of a new seamless earth system prediction model, Clim. Dynam., 39, 2611-2629, doi:10.1007/s00382-011-1228-5, 2011.

Hilgen, F., Krijgsman, W., Langereis, C., Lourens, L., Santarelli, A., and Zachariasse, W.: Extending the astronomical (polarity) time scale into the Miocene, Earth Planet. Sci. Lett., 136, 495-510, 1995.

Hilgen, F., Aziz, H. A., Krijgsman, W., Raffi, I., and Turco, E.: Integrated stratigraphy and astronomical tuning of the Serravallian and lower Tortonian at Monte dei Corvi (Middle-Upper Miocene, northern Italy), Palaeogeogr. Palaeoecol., 199, 229264, 2003.

Hilgen, F. J., Bissoli, L., Iaccarino, S., Krijgsman, W., Meijer, R., Negri, A., and Villa, G.: Integrated stratigraphy and astrochronology of the Messinian GSSP at Oued Akrech (Atlantic Morocco), Earth Planet. Sci. Lett., 182, 237-251, 2000. 
Hüsing, S., Hilgen, F., Aziz, H. A., and Krijgsman, W.: Completing the Neogene geological time scale between 8.5 and $12.5 \mathrm{Ma}$, Earth Planet. Sci. Lett., 253, 340-358, 2007.

Jochum, M., Jahn, A., Peacock, S., Bailey, D. A., Fasullo, J. T., Kay, J., Levis, S., and Otto-Bliesner, B.: True to Milankovitch: Glacial Inception in the New Community Climate System Model, J. Climate, 25, 2226-2239, doi:10.1175/JCLI-D-11-00044.1, 2012.

Khodri, M., Leclainche, Y., Ramstein, G., Braconnot, P., Marti, O., and Cortijo, E.: Simulating the amplification of orbital forcing by ocean feedbacks in the last glaciation, Nature, 410, 570-574, 2001.

Kutzbach, J. E., Chen, G., Cheng, H., Edwards, R., and Liu, Z.: Potential role of winter rainfall in explaining increased moisture in the Mediterranean and Middle East during periods of maximum orbitally-forced insolation seasonality, Clim. Dynam., 42, 10791095, doi:10.1007/s00382-013-1692-1, 2013.

Laepple, T. and Lohmann, G.: Seasonal cycle as template for climate variability on astronomical timescales, Paleoceanography, 24, doi:10.1029/2008PA001674, 2009.

Larrasoaña, J. C., Roberts, A. P., Rohling, E. J., Winklhofer, M., and Wehausen, R.: Three million years of monsoon variability over the northern Sahara, Clim. Dynam., 21, 689-698, doi:10.1007/s00382-003-0355-z, 2003.

Laskar, J., Robutel, P., Joutel, F., Gastineau, M., Correia, A., and Levrard, B.: A long-term numerical solution for the insolation quantities of the Earth, Astronom. Astrophys., 428, 261-285, 2004.

Leuschner, D. C. and Sirocko, F.: Orbital insolation forcing of the Indian monsoon - a motor for global climate changes?, Palaeogeogr. Palaeoecol., 197, 83-95, 2003.

Lin, J. L.: The double-ITCZ problem in IPCC AR4 coupled GCMs: Ocean-atmosphere feedback analysis, J. Climate, 20, 44974525, 2007.

Lourens, L., Becker, J., Bintanja, R., Hilgen, F., Tuenter, E., van de Wal, R., and Ziegler, M.: Linear and non-linear response of late Neogene glacial cycles to obliquity forcing and implications for the Milankovitch theory, Quaternary Sci. Rev., 29, 352-365, 2010.

Lourens, L. J., Antonarakou, A., Hilgen, F. J., Hoof, A. A. M. V., and Zachariasse, W. J.: Evaluation of the Plio-Pleistocene astronomical timescale, Paleoceanography, 11, 391-413, 1996.

Lourens, L. J., Wehausen, R., and Brumsack, H. J.: Geological constraints on tidal dissipation and dynamical ellipticity of the Earth over the past three million years, Nature, 409, 1029-1034, 2001.

Mantsis, D. F.: Atmospheric response to orbital forcing and 20th century sea surface temperatures, Ph.D. thesis, University of Miami, http://scholarlyrepository.miami.edu/oa_dissertations/ 597 (last access: 7 October 2015), 2011.

Mantsis, D. F., Lintner, B. R., Broccoli, A. J., Erb, M. P., and Clement, A. C., and Park, H.-S.: The Response of Large-Scale Circulation to Obliquity-Induced Changes in Meridional Heating Gradients, J. Climate, 27, 5504-5516, 2014.
Opsteegh, J., Haarsma, R., Selten, F., and Kattenberg, A.: ECBILT: a dynamic alternative to mixed boundary conditions in ocean models, Tellus, 50A, 348-367, 1998.

Paillard, D., Labeyrie, L., and Yiou, P.: Macintosh program performs time-series analysis, Eos, Transactions American Geophysical Union, 77, 379-379, 1996.

Rachmayani, R., Prange, M., and Schulz, M.: Intra-interglacial climate variability from Marine Isotope Stage 15 to the Holocene, Clim. Past Discuss., 11, 3071-3107, doi:10.5194/cpd-11-30712015, 2015.

Raymo, M. E. and Nisancioglu, K.: The 41 kyr world: Milankovitch's other unsolved mystery, Paleoceanography, 18, doi:10.1029/2002PA000791, 2003.

Reichart, G.-J.: Late Quaternary variability of the Arabian Sea monsoon and oxygen minimum zone, Ph.D. thesis, Utrecht University, http://dspace.library.uu.nl/handle/1874/274419 (last access: 7 October 2015), 1996.

Rossignol-Strick, M.: African monsoons, an immediate climate response to orbital insolation, Nature, 304, 46-49, 1983.

Rossignol-Strick, M.: Mediterranean Quaternary sapropels, an immediate response of the African monsoon to variation of insolation, Palaeogeogr. Palaeoecol., 49, 237-263, 1985.

Ruddiman, W. F.: Earth's Climate: Past and Future, W. H. Freeman \& Company, 2008.

Sierro, F., Ledesma, S., Flores, J., Torrescusa, S., and Martinez del Olmo, W.: Sonic and gamma-ray astrochronology: Cycle to cycle calibration of Atlantic climatic records to Mediterranean sapropels and astronomical oscillations, Geology, 28, 695-698, 2000.

Tiedemann, R., Sarnthein, M., and Shackleton, N. J.: Astronomic timescale for the Pliocene Atlantic $\delta 180$ and dust flux records of Ocean Drilling Program Site 659, Paleoceanography, 9, 619638, 1994.

Tuenter, E., Weber, S. L., Hilgen, F. J., and Lourens, L. J.: The response of the African summer monsoon to remote and local forcing due to precession and obliquity, Global Planet. Change, 36, 219-235, doi:10.1016/S0921-8181(02)00196-0, 2003.

Tzedakis, P. C.: Seven ambiguities in the Mediterranean palaeoenvironmental narrative, Quaternary Sci. Rev., 26, 2042-2066, 2007.

Vergnaud-Grazzini, C., Ryan, W. B., and Cita, M. B.: Stable isotopic fractionation, climate change and episodic stagnation in the eastern Mediterranean during the late Quaternary, Mari. Micropaleontol., 2, 353-370, 1977.

Vettoretti, G. and Peltier, W.: Sensitivity of glacial inception to orbital and greenhouse gas climate forcing, Quaternary Sci. Rev., 23, 499-519, 2004.

Zeeden, C., Hilgen, F. J., Hüsing, S. K., and Lourens, L. L.: The Miocene astronomical time scale 9-12 Ma: new constraints on tidal dissipation and their implications for paleoclimatic investigations, Paleoceanography, 29, 296-307, 2014. 